\title{
$X$. Description of a thermometer which marks the greatest degrees of heat and cold, from one time of observation to another, and may also register its own height at every instant
}

Alex. Keith Esq. F.R.S. F.A.S. Edin.

To cite this article: Alex. Keith Esq. F.R.S. F.A.S. Edin. (1798) X. Description of a thermometer which marks the greatest degrees of heat and cold, from one time of observation to another, and may also register its own height at every instant, Philosophical Magazine Series 1, 2:5, 61-65, DOI: $10.1080 / 14786449808676878$

To link to this article: http://dx.doi.org/10.1080/14786449808676878

曲 Published online: 18 May 2009.

Submit your article to this journal ๘

Џll Article views: 2

Q View related articles ¿ 
gard to dyeing wool and filk, in which it may be employed with fuccefs; and in giving an account of this difference, I think the caufe of it may be found in the nature of the gallnuts. I. The acid which they exclufively contain, as Berthollet has proved, facilitates the decompofition of the foap with which the cottons have been impregnated, and the oil then remains fixed in their tiffue, and in a greater quantity, as well as in a more intimate combination. 2. The gallnuts, which owe their development to animal bodies, retain a character of animalifation, which they tranfmit to the vegetable ftuff, and by thefe means augment its affinities with the colouring principle of the madder ; for it is well known of what utility animal fubftances are to facilitate this combination. This animalifation becomes ufelefs in operating upon woollen or filk.

X. Defcription of a Thermometer whicb marks the greateft Degrees of Heat and Cold, from one Time of Obfervation to anotber, and may alfo regifler its own Heigbt at every Inftant. By ALEX. Kext H, Efq. F.R.S. and F.A.S. Edin. From the Tranfactions of the Royal Society of Edinburgh, Vol. IV. ${ }^{2} 79^{8}$.

Thermometers have hitherto been defective for meteorological purpofes, in fo far as they only point out the degree of heat at the moment of infpecting them, but do not thow what the difference has been, from the time of one obfervation to another.

The ingenious Robert Hook, in the end of the laft century, mentions his intention of making a thermometer for the above purpofe ; but it does not appear that it was ever executed : neither does he explain how it was to have been done.

The thermometer, invented by Mr. James Six, as defcribed in the $72 \mathrm{~d}$ volume of the Philofophical Tranfactions of the 
Royal Society of London, is made to thow its greateft rife or fall from one period of obfervation to another. This is done by means of two fmall pieces of black glafs, which foat on two different furfaces of mercury, within two glars tubes hermetically fealed. Thefe floats, when raifed to their greateft height, adhere to the fides of the tube, by means of a pring of glafs, and become ftationary, although the mercury falls. After the obferver has noted the temperature, he, by a magnet held in his hand, draws down the float to the furface of the mercury, in confequence of a fmall bit of feel wire being enclofed in the float, and the inftrument is prepared for another obfervation. This is an ingenious invention, but requires too delicate workmanthip to be fit for common ufe : befides, it cannot be made to record the degrees of heat at intermediate periods.

The thermometer lately invented by Dr. Rutherford, of Balilith, and defcribed in the $3^{d}$ vol. of the Edinburgh Tranfactions, is alfo an ingenious contrivance, but has the fame defect of marking only the extreme points to which the liquor has rifen or fallen in two feparate glafs tubes.

Some years ago it occurred to me, that an air thermometer might be ufed for the purpofes required; and accordingly I read to this fociety a defcription of the inftrument. But having formed another inftrument of a more fimple conftruction, I beg leave to give a defcription of it.

A B, fig. I. (Plate I.) is a tube about 14 inches long, and $\frac{3}{4}$ of an inch calibre, of thin glars, fealed or clofed at top. 'To the bottom, which is bent upwards, there is joined a glafs tube $\boldsymbol{\eta}$ inches long, and ${ }_{i \sigma}$ ths of an inch calibre, open at top. The tube A B is filled with alcohol, and from $\mathbf{B}$ to $\mathbf{E}$ is filled with mercury.-As liquids are incompreffible by weight in any perceprible degree, neither the alcohol nor mercury will be affected by the weight of the atmofphere.

F D is a fcale of brafs or ivory, about $6 \frac{1}{2}$ inches long, divided in the ufual way. $E$ is a fmall conical piece of ivory or glals, of a proper weight, made to float on the furface of 
the mercury in the fmaller tube; to which float is joined a wire, termed the float-wire, reaching to $\mathrm{H}$, having a knee bent at a right angle, which raifes one index, and depreffes another, according as the mercury rifes or falls. This part of the apparatus is defended from wind or rain by means of a glafs tube $7 \frac{1}{2}$ inches long, clofed at top and open at bottom, fo wide as to fide eafily over the fcale, and, by means of a brafs rim cemented to it, made to fit exactly to the circular bafe of the fcale. This cover need not be taken off, except when the inftrument is to be prepared for an obfervation. [The operation of the float and indexes will be better underftood from fig. 4, where a fimilar apparatus, but belonging to a newly invented barometer, is reprefented on a larger fcale.]

F $G$ is the fcale fixed to a circular piece of wood or brafs $D$, through which the fmall tube is made to pafs. From $G$ to $F$ is a piece of the fmalleft gold wire ftretched along the fcale, fixed at the ends by two pins. L L are two indexes, formed of thin black oiled filk, pierced by the fmall wire in fuch a manner as to lide upwards and downwards with a very fmall force not more than two grains. $\mathrm{H}$, the knee of the float-wire before defcribed, is made to encompafs the fmall wire between the two indexes, fo that, when the float rifes, the upper index is moved upwards, and, when it defcends, it leaves the upper index ftationary, and puthes down the lower one, which is alfo left ftationary when the fioat rifes. When the inftrument is to be prepared for an obfervation, the one index is to be pulled down, and the other raifed, by means of a bit of wire, bent for the purpofe, until both of them touch the knee of the floatwire : and when it is again obferved, the upper index will point out the greateft degree of heat, and the lower the greateft degree of cold, fince the time they were fet.

If this thermometer is to be adapted to a piece of clockwork, in order to record the degrec $s$ of heat at each hour and minute of time, it ought to be made of larger dimen- 
fions. The large tube may be 40 inches long, and not.increafed in diameter; but the fmall tube ought to be enlarged in diameter, and not in length. The alcohol will thus be affected by heat or cold in as fhort a time as that before defribed.

It is unneceffary to explain the clock-work. It is fufficient to fay, that a hollow cylinder of any light fubftance, 7 inches long and 5 inches diameter, is made to revolve upon a vertical axis once in 31 days or a month; a piece of fmooth vellum or paper is put round this cylinder, pafted only at the joining, but fo as to make it adhere clofe to the cylinder: on this are drawn $3 \mathrm{I}$ equal perpendicular divifions, numbered at top, $1,2,3$, \&c. each of which is fubdivided into fix parts, to anfwer to 4 hours. The length of this cylinder is divided by lines furrounding it, or zones, in fuch number as to cørrefpond to the fcale of Fahrenheit's therm. viz. from 0 to $100^{\circ}$. Thefe divifions ought to be engraved on copper, and a number of impreffions thrown off on fmooth or vellum paper, in order that one may be ready to put on each month.

M N, fig. 2. reprefents the cylinder covered with one of thefe impreffions. P P is the fcale fixed to the frame in which the cylinder turns. The divifions on this fcale correfpond to thofe on the cylinder.

$Q$ is a piece of black lead pencil, joined to the end of the float-wire, in place of the knee before mentioned. This pencil is made to prefs lightly on the cylinder, by means of the fmall weight $R$. And as the pencil rifes or falls by heat and cold, it marks the degrees on the fcale of the cylinder; and the cylinder being conftantly revolving, the divifion for each day and parts of a day will fucceffively be marked by the pencil, which will leave a trace, defcribing an undulated line, diftinctly delineating the temperature of each day through the month. Thefe papers, when taken off and bound together, will make a complete regifter of the temperature for the year; or, if they are pafted to one another, 
in their order, they will form a thermometrical chart, by which the variations of heat and cold, during the year, may all be feen and compared by one glance of the eye.

By infpecting fig. 2. the effect of the inftrument may be feen. It appears that the paper had been put on the cylin. der the firt day of the month, at midday, when the thermometer ftood at $45^{\circ}$; that it fell gradually till midnight to $25^{\circ}$; thereafter it rofe till the $2 \mathrm{~d}$, at $\mathbf{I}$ P. M. when it ftood at $42^{\circ}$; then it defcended at midnight to $35^{\circ}$; that on the $4^{\text {th }}$ at noon it role to 50 ; and at noon the 10 th of the month it ftands at $40^{\circ}$.

If 3 inches be added to the length of the cylinder, it may be made to delineate the variations of the barometer as well as the thermometer, and thereby to form a complete chart or view of the progrefs of both of them. And if inftruments of this kind were kept in different parts of the country, and their charts compared together, it would afford much information with regard to meteorology.

XI. Defcription of a Barometor, wbicb marks the Rife and Fall of the Mercury from two different Times of Obfervation; invented by Aгех. KEIтн, E/q. F.R.S. and F. A.S. Edin. From the Tranfactions of the Royal Society of Edinburgh, $V o l$. $I V$. 1798 .

A B C D, fig. 3. (Plate I.) is a glafs tube bent in the manner repefented, open at $D$, and hermetically fealed at $A$. From $A$ to $B$ is 8 inches long, and about $\frac{3}{4}$ of an inch calibre. From $\mathrm{B}$ to $\mathrm{C}_{3} \mathrm{I}_{\frac{x}{4}}$ inches long, and about $\frac{1}{4}$ inch calibre. And from $\mathrm{C}$ to $\mathrm{D}_{4}^{\frac{1}{3}}$ inches long, and $\frac{\mathrm{r}}{2}$ inch calibre. The tube is filled with mercury, the length from $\mathbf{A}$ to $\mathrm{E}$ being $29 \frac{\mathrm{I}}{2}$ inches. When the tube is hung perpendicularly, the mercury will fall from $B$ towards $E$, leaving a vacuum from $A$ to $B$. When the atmofphere becomes heaVor. II. 